\title{
From Communicative Competence to Language Development
}

\author{
Çağrı Tuğrul Mart ${ }^{1}$ \\ ${ }^{1}$ Ishik University, Erbil, Iraq \\ Correspondence: Çağrı Tuğrul Mart, Ishik University, Erbil, Iraq. E-mail: cagri.mart@ishik.edu.iq
}

Received: October 1, 2017 Accepted: November 2, 2017 Online Published: December 23, 2017

doi:10.5539/ijel.v8n2p163 URL: http://doi.org/10.5539/ijel.v8n2p163

\begin{abstract}
Communicative competence is a term which alludes to tacit knowledge of language and the ability to understand and use the language effectively for communication purposes. Simply put, it refers to the ability of forming correct utterances and using them appropriately. This paper looks briefly at the concept of communicative competence and how it is acquired. The second issue that the paper raises is the components of different communicative competence models which are seen as central to further language development. Finally, the paper summarizes the essence and core tenets of communicative language teaching.
\end{abstract}

Keywords: communicative competence, communicative language teaching, language development

\section{The Communicative Competence Model}

The terms "competence" and "performance" have been introduced by Chomsky (1965) in modern linguistics and have been frequently a focus of discussions of second language approaches (Canale \& Swain, 1980). In view of Chomsky (1965) these terms have both a weak sense and a strong sense. Chomsky's weak claim is that while competence refers to grammatical knowledge and language aspects, performance comprises actual use of language. In speaking of performance, it is what ensues from putting proficiency to use (Taylor, 1988). The strong sense of the competence-performance distinction is that competence is concerned with linguistic system, whereas performance focuses on psychological factors during speech production (Chomsky, 1965). Campbell \& Wales (1970) and Hymes (1972) extended Chomsky's competence-performance distinction and became the first to assert that the distinction "provides no place for consideration of the appropriateness of sociocultural significance of an utterance in the situational and context" (Canale \& Swain, 1980, p. 4) where it is used. Campbell \& Wales (1970) and Hymes (1972) proposed the term "communicative competence" which entails not only grammatical competence but also sociolinguistic and contextual competence (Canale \& Swain, 1980). To put the matter at its most basic, rules of grammar and rules of language use are woven together in their broader view of communicative competence.

Savignon (1972) views communicative competence as "the ability to function in a truly communicative setting" (p. 8). It seems reasonable for her to describe communicative competence as interaction between people for negotiation of meaning. Savignon (1972) makes reference to willingness to express oneself in the language, skillfulness at using grammatical skills, and paralinguistic aspects of the language being learned to communicate in a given language. 


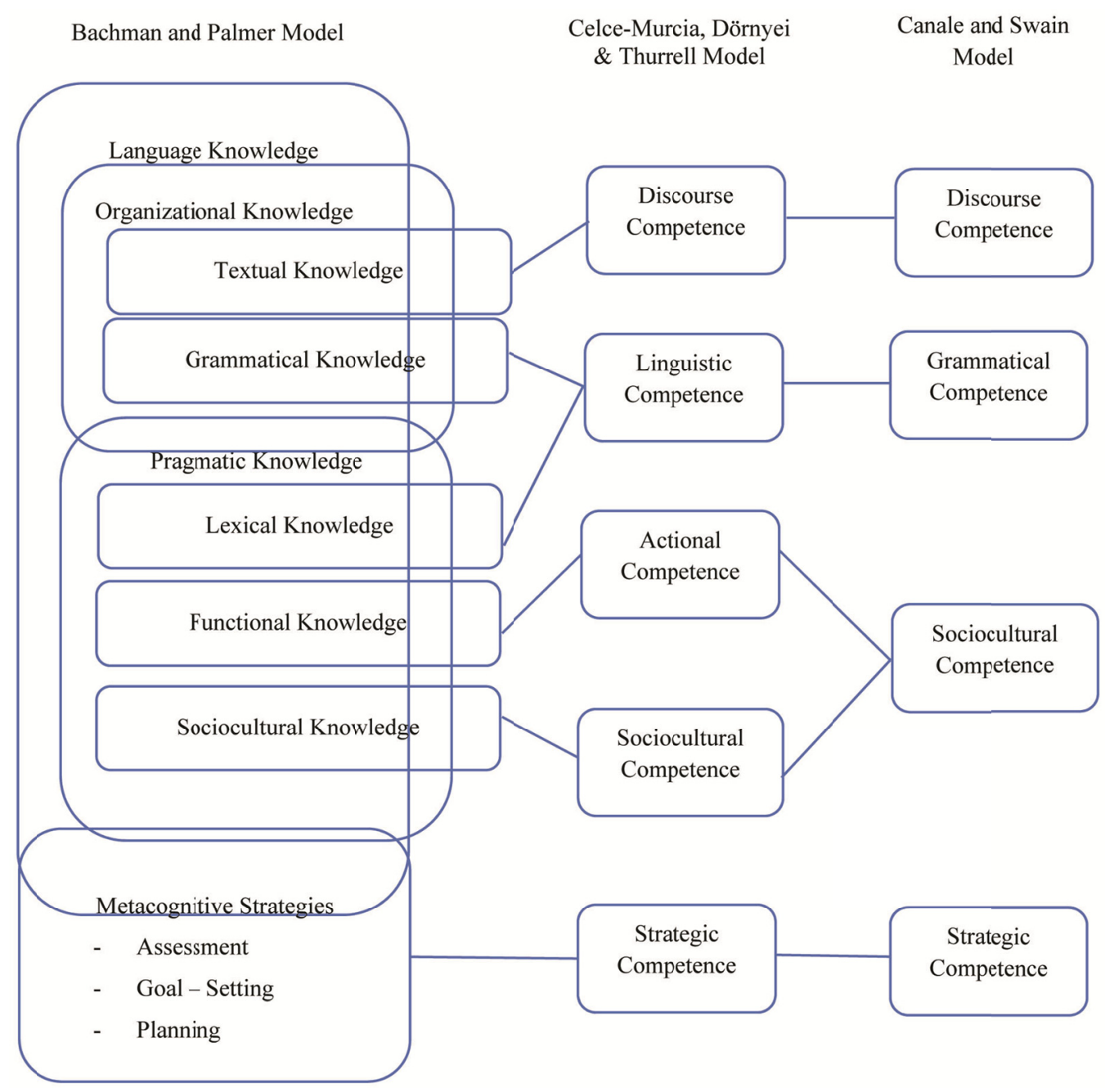

Figure 1. Comparison of communicative competence models

Source: Adapted from "Communicative Competence: A pedagogically Motivated Model with Content Specifications," by Celce-Murcia, Dörnyei and Thurrell, 1995, Issues in Applied Linguistics, 6, 12.

\section{Different Models of Communicative Competence}

The first comprehensive model of communicative competence was developed by Canale \& Swain (1980), who defined the term as knowledge of language and its use in actual and meaningful communication circumstances, posited four components: grammatical competence refers to the knowledge of language system; sociolinguistic competence involves sociocultural code of language use; discourse competence pertains to combining language structures into cohesive texts; strategic competence is pertinent to communication strategies as a basis for efficiency in communication development. The mastery of linguistic and structural properties, appropriate comprehension of utterances by learners in different social contexts, skillful combination of ideas to achieve cohesion, and effective use of verbal and non-verbal communication strategies to overcome communication breakdowns, are elements what communicative competence entails.

Another communicative competence model has been proposed by Bachman (1990) and Bachman \& Palmer (1996) which emerged as an elaboration of the Canale \& Swain model (1980). Their elaborated model consisted of two main categories which were broken down into subcategories: On the one hand, organizational knowledge is relevant to language structure components to produce accurate sentences and form texts. Organizational knowledge is divided into two subcategories: grammatical and textual knowledge. Pragmatic knowledge on the other hand bears on components which relate words and utterances for intentions of learners. Pragmatic knowledge is divided into three subcategories: lexical, functional and sociocultural knowledge. Lexical knowledge includes the knowledge of words, and functional knowledge is pertinent to the bond between utterances, intentions and communicative purposes of learners. Strategic competence in Bachman and Palmer 
(1996) model is the knowledge of language which interacts with metacognitive strategies that render learners to involve in goal setting, assessment of communicative sources, and planning.

More recently, Celce-Murcia, Dörnyei, \& Thurrell (1995) has proposed a model of communicative competence which has five components: discourse competence is the core of communicative competence and is concerned with "selection, sequencing and arrangement of words, structures and utterances to achieve a unified spoken or written text" (p. 13); linguistic competence is related to basic communication elements involving sentence patterns, lexical resources, phonological and morphological systems; actional competence is considered as the ability to understand and convey communicative intention; sociocultural competence comprises knowledge of learners in expressing messages appropriately within cultural and social context of communication; strategic competence is conceptualized as knowledge of communication strategies and its use skillfully by learners.

The model proposed by Celce-Murcia et al. (1995) differs from the model of Canale \& Swain (1980). First, rather than "grammatical competence" the term "linguistic competence" was used to indicate that this component connotes syntax, morphology, phonology and lexis. Second, the term "sociocultural competence" was used rather than "sociolinguistic competence" to differentiate it from actional competence and to underline the fact that resources in language includes actional, discourse, and linguistic components whereas sociocultural knowledge is a requisite for implementation of language resources in other components.

\section{Communicative Language Teaching}

The essence of Communicative Language Teaching (henceforth CLT) is the involvement of learners in communication to develop their communicative competence (Savignon, 2007). For Savignon (2007) CLT constitutes an arena to promote functional language ability participating in communicative situations, thus CLT stems from a multidisciplinary perspective including linguistics, sociology, philosophy, educational research and psychology. CLT does not forsake the teaching of grammar because communication cannot take place in the absence of grammar (Savignon, 1991). Littlewood (1981) favors the integration of grammatical and functional teaching and states that "one of the most characteristic features of CLT is that it pays systematic attention to functional as well as structural aspects of language" (p. 1). CLT is a theory of language teaching that views language as a system for meaning expression; moreover language is used to create interaction and communication by learners who are committed to communicative competence and whose participation include not merely grammatical features but also functional categories (Richards \& Rodgers, 2001). This approach emphasizes the practical aspect of the second language acquisition.

\section{The Core Tenets of Communicative Language Teaching}

In communication language teaching language should be presented by means of language use, wherethrough learners perceive the language system and apply it to their real conversation (Widdowson, 1978). Berns (1990) summarizes the core tenets of CLT as follows:

a) Communication has emerged as a significant building block in language teaching

b) Diversity is seen as part of language development

c) Competence of learners are considered relatively with reference to correctness

d) Culture is viewed to have an instrumental role in structuring communicative competence of learners

e) It is essential that learners are engaged in using the language for a variety of purposes

f) There is not a single methodology or a technique prescribed

g) There is more than one language variety as a model for teaching and learning

h) Language use refers to the competence development of learners in the interpersonal, ideational and textual functions.

CLT is learner-centered and embraces both the goals and the processes of classroom learning (Savignon, 1991). Nunan (1991) characterizes the features of communicative approach to language teaching in the following way:

a) A frequently cited dimension of CLT is its focus on learning to communicate which rests on interaction in the target language.

b) Introduction of authentic texts into the communicative events subsidizes learner participation.

c) The attainment of communicative competence requires learners to focus not only on language but also on the learning process itself. 
d) CLT is experience-based view of second language teaching, thus personal experiences enhance classroom learning.

e) The relation of classroom language learning to the use of language in social context outside the classroom enables learners to activate the language.

Brown (2000) proposes six features of a communicative approach. First, classroom goals involve all the components of communicative competence. Second, language techniques are outlined to immerse learners in the authentic, functional and pragmatic use of language for meaningful purposes and organizational forms are aspects of language for attainment of these purposes. Third, accuracy and fluency are seen as central to communicative techniques. The eminence of fluency in this instance is more apparent than accuracy. Fourth, learners have to be prompted by productive and receptive dimensions of language use in both oral and written texts for communicative competence. Fifth, learning styles are valued as much for the impact they have on learning process. Sixth, learners need to experience communication through participating in the negation of meaning. All these features play important role in the development of communicative competence.

Canale \& Swain (1980) present five principles that guide the development of a communicative approach. First, communicative competence requires integrating knowledge with respect to components of communicative competence for the learner. Second, it is important to base a communicative approach on communication needs of learners. Third, taking part in realistic second language situations meet communicative needs of learners. Fourth, in language learning it is significant to make optimal use of aspects of communicative competence particularly at the early stages. Fifth, the primary purpose of a communicative-oriented language program is to provide experience, practice and information for learners as an underlying construct of communication.

Piepho (1981) in an effort to discuss the objectives of communicative approach considers language as a means of negotiation of meaning. Language is an object of learning; in light of this viewpoint learners have a necessity of engaging in communicative language tasks to produce, manipulate, comprehend and interact in the target language. The pedagogic rationale for welcoming a wide range of communicative tasks lies on the claim that they influence development of communicative competence. Brumfit (1984) advocates the use of communicative tasks for their significance in accuracy and fluency. They enable to discover new linguistic forms in a conversation and aid learners to activate their linguistic knowledge during the course of communicating. Ellis (1982) lays down the following characteristics of communicative tasks:

a) Learners must have a communicative purpose

b) The emphasis should be laid upon message rather than linguistic code

c) There must be gaps which demand learners to fill

d) Opportunities are needed for learners to participate in meaning negotiation

e) Resources, verbal or non-verbal, must be chosen by learners in performing the task

Richards (2006), in seeking to bring the core assumptions of CLT to attention, makes it clear that second language learning is best advanced by active participation in meaningful communication. Learning tasks and exercises overwhelmingly support negotiation of meaning and make learners well aware of how language is used. In the meantime, much attention has been devoted to four skill areas of reading, speaking, listening and writing for the establishment of communicative functions. Language learning involves the successful use of language for communication. Effective communication relies on the use of language skills competently. Clear and consistent use of language is necessary in the attainment of communicative competence.

\section{Conclusion}

Communicative competence refers to the ability to interact with other people for negotiation of meaning. Different models have been proposed in the realm of communicative competence. While the first communicative competence model proposed by Canale and Swain posited four components, the model proposed by Bachman and Bachman and Palmer consisted of two main categories which were broken down into subcategories. More recently, another model which differs from the model of Canale and Swain has been proposed by Celce-Murcia, Dörnyei and Thurrell. Communicative language teaching aims to develop communicative competence through involvement in communicative situations.

\section{References}

Bachman, L. F. (1990). Fundamental Considerations in Language Testing. Oxford: Oxford University Press.

Bachman, L. F., \& Palmer, A. S. (1996). Language Testing in Practice. Oxford: Oxford University Press. 
Berns, M. (1990). Contexts of Competence: English Language Teaching in Non-Native Contexts. New York: Plenium. https://doi.org/10.1007/978-1-4757-9838-8

Brown, H. D. (2000). Teaching by Principles: An interactive Approach to Language Pedagogy. NY: Longman.

Brumfit, C. J. (1984). Communicative Methodology in Language Teaching. Cambridge: Cambridge University Press.

Campbell, R., \& Wales, R. (1970). The study of language acquisition. In J. Lyons (Ed.), New Horizons in Linguistics (pp. 242-260). Harmondsworth: Penguin Books.

Canale, M., \& Swain, M. (1980). Theoretical bases of communicative approaches to second language teaching and testing. Applied Linguistics, 1(1), 1-47. https://doi.org/10.1093/applin/1.1.1

Celce-Murcia, M., Dörnyei, Z., \& Thurrell, S. (1995). Communicative competence: A pedagogically motivated model with content specifications. Issues in Applied Linguistics, 6(2), 5-35.

Chomsky, N. (1965). Aspects of the Theory of Syntax. Cambridge, MA: MIT Press.

Ellis, R. (1982). Informal and formal approaches to communicative language teaching. The ELT Journal, 36, 73-81. https://doi.org/10.1093/elt/36.2.73

Hymes, D. H. (1972). On communicative competence. In J. B. Pride \& J. Holmes (Eds.), Sociolinguistics: Selected Readings (pp. 269-293). Harmondsworth: Penguin.

Littlewood, W. (1981). Communicative Language Teaching. Cambridge: Cambridge University Press.

Nunan, D. (1991). Communicative tasks and the language curriculum. TESOL Quarterly, 25(2), 279-295. https://doi.org/10.2307/3587464

Piepho, H. E. (1981). Establishing objectives in the teaching of English. In C. Candlin (Ed.), The Communicative Teaching of English: Principles and an Exercise Typology (pp. 8-23) London: Longman.

Richards, J. (2006). Communicative Language Teaching Today. Cambridge: Cambridge University Press.

Richards, J., \& Rodgers, T. (2001). Approaches and Methods in Language Teaching. Cambridge: Cambridge University Press. https://doi.org/10.1017/CBO9780511667305

Savignon, S. J. (1972). Communicative Competence: An Experiment in Foreign-Language Teaching. Philadelphia: Center for Curriculum Development.

Savignon, S. J. (1991). Communicative language teaching: State of the art. TESOL Quarterly, 25(2), 261-277. https://doi.org/10.2307/3587463

Savignon, S.J. (2007). Beyond communicative language teaching: What's head? Journal of Pragmatics, 39 , 207-220. https://doi.org/10.1016/j.pragma.2006.09.004

Taylor, D. (1988). The meaning and use of the term "competence" in linguistics and applied linguistics. Applied Linguistics, 9, 148-168. https://doi.org/10.1093/applin/9.2.148

Widdowson, H. G. (1978). Teaching Language as Communication. Oxford: Oxford University Press.

\section{Copyrights}

Copyright for this article is retained by the author(s), with first publication rights granted to the journal.

This is an open-access article distributed under the terms and conditions of the Creative Commons Attribution license (http://creativecommons.org/licenses/by/4.0/). 